\title{
Physiological Basis for Metamifop Selectivity on Bermudagrass (Cynodon dactylon) and Goosegrass (Eleusine indica) in Cool-Season Turfgrasses
}

\begin{abstract}
Patrick E. McCullough, Jialin Yu, Mark A. Czarnota, and Paul L. Raymer*
Bermudagrass and goosegrass are problematic weeds with limited herbicides available for POST control in creeping bentgrass. Metamifop effectively controls these weeds with greater selectivity in cool-season grasses than other ACCase inhibitors. The objectives of this research were to determine the physiological basis for metamifop selectivity in turfgrasses. In greenhouse experiments, metamifop rate required to reduce shoot biomass $50 \%$ from the nontreated $\left(\mathrm{GR}_{50}\right)$ at 4 wk after treatment was $>6,400,2,166$, and $53 \mathrm{~g}$ ai ha $^{-1}$ for creeping bentgrass, Kentucky bluegrass, and goosegrass, respectively. The $\mathrm{GR}_{50}$ for bermudagrass treated with diclofop-methyl or metamifop was 2,850 and $60 \mathrm{~g} \mathrm{ha}^{-1}$, respectively. In laboratory experiments, peak absorption of ${ }^{14} \mathrm{C}$-metamifop was reached at 48, 72, and $96 \mathrm{~h}$ after treatment (HAT) for goosegrass, creeping bentgrass and Kentucky bluegrass, respectively. Grasses translocated $<10 \%$ of the absorbed radioactivity out of the treated leaf at 96 HAT, but creeping bentgrass translocated three times more radioactivity than goosegrass and Kentucky bluegrass. Creeping bentgrass, Kentucky bluegrass, and goosegrass metabolized 16, 14 , and $25 \%$ of ${ }^{14} \mathrm{C}$-metamifop after $96 \mathrm{~h}$, respectively. Goosegrass had around two times greater levels of a metabolite at retention factor 0.45 than creeping bentgrass and Kentucky bluegrass. The concentration of metamifop required to inhibit isolated ACCase enzymes $50 \%$ from the nontreated $\left(\mathrm{I}_{50}\right)$ measured $>100,>100$, and $38 \mu \mathrm{M}$ for creeping bentgrass, Kentucky bluegrass, and goosegrass, respectively. In other experiments, foliar absorption of ${ }^{14}$ C-metamifop in bermudagrass was similar to ${ }^{14} \mathrm{C}$-diclofop-methyl. Bermudagrass metabolized 23 and $60 \%$ of the absorbed ${ }^{14} \mathrm{C}$-diclofop-methyl to diclofop acid and a polar conjugate after $96 \mathrm{~h}$, respectively, but only $14 \%$ of ${ }^{14} \mathrm{C}$-metamifop was metabolized. Isolated ACCase was equally susceptible to inhibition by diclofop acid and metamifop $\left(\mathrm{I}_{50}=0.7 \mu \mathrm{M}\right)$, suggesting degradation rate is associated with bermudagrass tolerance levels to these herbicides. Overall, the physiological basis for metamifop selectivity in turfgrass is differential levels of target site inhibition.

Nomenclature: ACCase, acetyl-CoA carboxylase; metamifop, (2R)-2-[4-[(6-chloro-2-benzoxazolyl) oxy]phenoxy]- $N$-(2-fluorophenyl)- $N$-methylpropanamide; bermudagrass, Cynodon dactylon L. (Pers.) $\times$ C. transvaalensis Burtt Davy 'Princess-77'; creeping bentgrass, Agrostis stolonifera L. 'Penn A-4'; goosegrass, Eleusine indica (L.) Gaertn.; Kentucky bluegrass, Poapratensis L. 'Midnight'.
\end{abstract}

Key words: Fate, graminicide, metabolism, uptake.

Creeping bentgrass is used for golf greens, tees, and fairways in the U.S. transition zone and coolhumid region. Goosegrass is a troublesome weed that exhibits competitive growth with creeping bentgrass during summer months. PRE herbicides may control goosegrass in creeping bentgrass fairways, but there are no effective chemistries registered for use in golf greens (Hart et al. 2004; Johnson 1994a). Fenoxaprop is an aryloxyphenoxypropionate (AOPP) herbicide labeled for POST control of goosegrass in creeping bentgrass fairways. The AOPP herbicides inhibit acetyl-CoA carboxylase (ACCase)

\footnotetext{
DOI: $10.1614 / \mathrm{WS}-\mathrm{D}-15-00107.1$

${ }^{*}$ First, second, and fourth authors: Associate Professor, Postdoctoral Researcher, and Professor, Crop and Soil Sciences Department, University of Georgia, Griffin, GA 30223; third author, Associate Professor, Department of Horticulture, Uni versity of Georgia, Griffin, GA 30223. Corresponding author's E-mail: pmccull@uga.edu
}

enzymes that catalyze the carboxylation of acetyl Co-A to malonyl-CoA in fatty acid biosynthesis (Cronan and Waldrop 2002). Fenoxaprop is not labeled for golf greens; thus, application rates must be reduced from other cool-season turfgrasses to minimize creeping bentgrass injury (Henry and Hart 2004; Johnson 1994a). Currently no other herbicides are labeled for POST goosegrass control in creeping bentgrass, and new chemistries are needed with improved selectivity.

Hybrid bermudagrass [Cynodon dactylon L. (Pers.) $\times C$. transvaalensis Burtt-Davy] is often grown adjacent to creeping bentgrass golf greens in the U.S. transition zone, and encroachment reduces turfgrass quality. Ethofumesate and fenoxaprop suppress bermudagrass populations in tolerant cool-season grasses such as Kentucky bluegrass (Johnson 1994b; Meyer and Branham 2006). However, sequential applications of these herbicides in summer cause 
excessive $(>30 \%)$ injury to creeping bentgrass (Carroll et al. 1992; Johnson and Carrow 1993, 1995). Siduron is a PRE herbicide used to inhibit bermudagrass encroachment in creeping bentgrass golf greens, but applications often provide erratic levels of suppression (Johnson and Carrow 1989, 1993; Siviour and Schultz 1984).

Metamifop is an AOPP herbicide used in rice (Oryza sativa L.) and turfgrass for POST control of grassy weeds in Japan (Hae-Jin et al. 2002). Compared with fenoxaprop, creeping bentgrass has superior tolerance to metamifop rates required for controlling bermudagrass and goosegrass (Dernoeden 1989; Hart and Mansue 2010; McElroy and Rose 2009; Shim and Johnson 1992). Flessner and McElroy (2011) reported creeping bentgrass and Kentucky bluegrass had no injury after $30 \mathrm{~d}$ from metamifop at $800 \mathrm{~g}$ ai ha ${ }^{-1}$ applied singly or $400 \mathrm{~g}$ $\mathrm{ha}^{-1}$ applied sequentially. Conversely, creeping bentgrass and Kentucky bluegrass were injured $\sim 80$ and $40 \%$ by fenoxaprop at $100 \mathrm{~g} \mathrm{ha}^{-1}$. In New Jersey, summer applications of metamifop at $800 \mathrm{~g} \mathrm{ha}^{-1}$ caused $<15 \%$ injury to creeping bentgrass and Kentucky bluegrass (Hart and Mansue 2010). The researchers also noted that metamifop at $200 \mathrm{~g}$ $\mathrm{ha}^{-1}$ controlled two- to three-tiller goosegrass $\geqslant 83 \%$ and was equivalent to fenoxaprop at $100 \mathrm{~g}$ $\mathrm{ha}^{-1}$. Sequential metamifop applications at $400 \mathrm{~g}$ $\mathrm{ha}^{-1}$ also suppress bermudagrass with comparable efficacy to fenoxaprop (Doroh et al. 2011). Thus, metamifop could provide practitioners an alternative herbicide to AOPPs currently available for controlling these weeds in creeping bentgrass.

Although AOPP herbicides have been used for years, there has been limited reporting on the physiological basis for selectivity in turfgrasses. Metamifop is an efficacious graminicide for cool-season grasses, and further research is warranted to identify the mechanisms associated with selectivity. Further research is also needed to investigate the differential behavior of ACCase inhibitors for controlling bermudagrass. The objective of this research was to evaluate the physiological basis for metamifop selectivity for bermudagrass and goosegrass control in cool-season turfgrasses.

\section{Materials and Methods}

Plant Material. 'Princess' bermudagrass (Pennington Seed Inc., Madison, GA 30650), 'Penn A-4' creeping bentgrass (Tee-2-Green Corp., Hubbard, OR 97032), 'Midnight' Kentucky bluegrass (Preferred Seed, Buffalo, NY 14227), and goosegrass were seeded in pots at the University of Georgia
(UGA) Griffin Campus. Goosegrass seed was collected locally from indigenous plants at the UGA Griffin Campus $\left(33.25^{\circ} \mathrm{N}, 84.30^{\circ} \mathrm{W}\right)$. Pots measured $3.8-\mathrm{cm}$ surface diameter with $20-\mathrm{cm}$ depths, and soil was a sand: peat moss mixture $(80: 20 \mathrm{v} /$ v). Creeping bentgrass and Kentucky bluegrass were established in a greenhouse set for 23/18 C (day/night temperatures), and bermudagrass and goosegrass were established in a greenhouse set for $32 / 25$ C. Pots were watered regularly to promote germination and prevent soil moisture deficiencies. Grasses received fertigation biweekly (MacroN 287-14 Sprayable Fertilizer, Lesco Inc., Cleveland, $\mathrm{OH}$ ) and were allowed to reach a four- to seven-tiller growth stage before treatments.

Evaluation of Turfgrass Tolerance to Metamifop. Greenhouse experiments were conducted to evaluate the differential tolerance levels of the aforementioned grasses to metamifop. Plants selected for treatments were acclimated in a greenhouse set for $32 / 25 \mathrm{C}$ (day/night) for $1 \mathrm{wk}$ before treatments. A titration of nine metamifop rates (10\% emulsifiable concentrate [EC], Summit Agro International Ltd., Tokyo, Japan) ranging from 25 to $6,400 \mathrm{~g}^{\text {ai }} \mathrm{ha}^{-1}$ was applied to creeping bentgrass, goosegrass, and Kentucky bluegrass.

Treatments were applied with a spray chamber calibrated to deliver $187 \mathrm{~L} \mathrm{ha}^{-1}$ with an $8002 \mathrm{E}$ flat-fan nozzle (TeeJet Spraying Systems Co., Roswell, GA 30075). Injury was visually evaluated 2 and $4 \mathrm{wk}$ after treatment (WAT) on a scale ranging from $0 \%$ (no injury) to $100 \%$ (total desiccation). Shoots were harvested 4 WAT, oven-dried for $72 \mathrm{~h}$, and then weighed.

Bermudagrass Tolerance to Diclofop-Methyl and Metamifop. In separate experiments, bermudagrass was treated with diclofop-methyl (Illoxan 3EC, Bayer Environmental Science, Research Triangle Park, NC) or metamifop at the aforementioned rates. A nontreated check was included. Hybrid bermudagrass is tolerant to diclofop-methyl, another ACCase inhibitor, and applications from 600 to $1,000 \mathrm{~g} \mathrm{ha}^{-1}$ provide effective $(>90 \%)$ control of goosegrass in field experiments (McCarty 1991). Thus, diclofop-methyl was chosen for comparison to metamifop because of the differential tolerance levels reported in bermudagrass. Treatments were made with the aforementioned methodology. Injury and shoot biomass were measured as previously described.

Absorption and Translocation. Experiments were conducted to evaluate absorption and translocation 
of ${ }^{14} \mathrm{C}$-metamifop in creeping bentgrass, goosegrass, and Kentucky bluegrass. Grasses were placed in a growth chamber set for $30 / 20 \mathrm{C}$ with a 12 -h photoperiod of $350 \mu \mathrm{mol} \mathrm{m}{ }^{-2} \mathrm{~s}^{-1}$ for $1 \mathrm{wk}$ before treatments. Pots were watered as needed to prevent plant wilt.

Before treatments, the second fully expanded leaf on grasses was covered with flexible film (Parafilm, Bemis Company Inc., Neenah, WI 54956). Metamifop was then applied at $400 \mathrm{~g} \mathrm{ha}^{-1}$ with a $\mathrm{CO}_{2-}$ pressured sprayer calibrated to deliver $187 \mathrm{~L} \mathrm{ha}^{-1}$ spray volume. Immediately after broadcast treatments, film was removed, and the leaf received a total of $416 \mathrm{~Bq}$ of ${ }^{14} \mathrm{C}$-metamifop (Institute of Isotopes Co. Ltd., Budapest, Hungary; $2.4 \mathrm{MBq}$ $\mathrm{mg}^{-1}$, labeled at 6-chloro-2-benzoxazolyl benzene ring, $99.5 \%$ chemical purity) in two $1-\mu$ l droplets from a $5-\mu l$ syringe. Formulated herbicide was added to bring treatment solutions to $2.1 \mu \mathrm{g}$ of metamifop $\mu^{-1}$. A nonionic surfactant (Activator 90, Loveland Products Inc., Greeley, CO 80632-1286) was added to the spotting solution at $0.25 \%(\mathrm{v} / \mathrm{v})$ to facilitate deposition of droplets on leaves.

Plants were harvested (roots + shoots) at 1, 6, 24, 48,72 , or $96 \mathrm{~h}$ after treatment (HAT). The treated leaf was excised from the plant with shears. The base of the leaf was held with forceps and rinsed with $10 \mathrm{ml}$ of acetonitrile toward the tip in a 20$\mathrm{ml}$ glass scintillation vial. Nontreated shoots were then separated from roots with shears, and samples were oven-dried at $40 \mathrm{C}$ for $7 \mathrm{~d}$. The rinsate was evaporated in a forced-air hood, and radioactivity was quantified with liquid scintillation spectroscopy (LSC; Beckman LS 6500 ${ }^{\circledR}$, Beckman Coulter Inc., Fall River, MA 02720). Samples were combusted in a biological oxidizer (OX-500, R.J. Harvey Instrument Corp., 11 Jane Street, Tappan, NY 10983) for $2 \mathrm{~min}$, and radioactivity was quantified using LSC. All plant parts were oxidized together for samples harvested from 1 to 72 HAT. The treated leaf, nontreated shoots, and roots were oxidized separately for plants harvested at $96 \mathrm{HAT}$.

Foliar absorption was quantified by dividing the total radioactivity recovered in plants by the amount applied. Translocation was calculated by dividing the ${ }^{14} \mathrm{C}$ recovered in nontreated shoots and roots by the total amount of radioactivity absorbed per plant. Radioactivity recovery was quantified by dividing the sum of absorbed and adsorbed radioactivity by the total amount applied.

Metabolism. Experiments were conducted to evaluate creeping bentgrass, goosegrass, and Kentucky bluegrass metabolism of ${ }^{14} \mathrm{C}$-metamifop using a similar methodology from previous research on ${ }^{14} \mathrm{C}$-diclofop-methyl metabolism (DePrado et al. 2005). Grasses were treated as previously described, but the radioactivity levels were increased to $4 \mathrm{kBq}$ per plant. Plants were harvested at 24, 48, and 96 HAT using the aforementioned methodology. The treated leaf and nontreated shoots were combined for metabolism evaluations, and roots were discarded. Samples were stored at $-20 \mathrm{C}$ for $<14 \mathrm{~d}$ before analysis.

Shoots were minced and homogenized in $20 \mathrm{ml}$ of $90: 10$ acetone : water for $30 \mathrm{~s}$ (FSH 125, Fisher Scientific LLC, 300 Industry Drive, Pittsburg, PA 15275). The homogenizer was rinsed with an additional $5 \mathrm{ml}$ of acetone solution. Samples were sonicated for $1 \mathrm{~h}$ (Branson CPX8800H, Branson Ultrasonic Corporation, Danbury, CT 06810), and then centrifuged at $4,800 \times g$ for $30 \mathrm{~min}$. The supernatant was transferred to separate tubes (Thermo Scientific, 320 Rolling Ridge Drive, Bellefonte, PA 16823), and radioactivity from a 2.5-ml aliquot was measured with LSC. Residue was combusted in a biological oxidizer (OX-500, R.J. Harvey Instrument Corp.) for $2 \mathrm{~m}$ and radioactivity was quantified with LSC.

The supernatant was then evaporated at $40 \mathrm{C}$ in a forced-air hood. Vials were cooled, and samples were resuspended in $40 \mu \mathrm{l}$ of acetone before being spotted on $20 \times 20-\mathrm{cm}$ thin layer chromatography (TLC) plates. Each plate was divided into seven lanes, including stock ${ }^{14} \mathrm{C}$-metamifop diluted in acetone. The plates were developed to $16 \mathrm{~cm}$ in a glass chamber using benzene : acetic acid $(10: 1)$. Metabolites were detected with a radiochromatography scanner (Bioscan System 200 Imaging Scanner, Bioscan, 4590 MacArthur Boulevard NW, Washington, DC 20007) connected to a computer equipped with Laura Chromatography Data Collection and Analysis Software ${ }^{\circledR}$ (LabLogic System Inc., 1040 E Brandon Boulevard, Brandon, FL 33511).

In separate experiments, ${ }^{14} \mathrm{C}$-metamifop metabolism in bermudagrass was compared with ${ }^{14} \mathrm{C}$ diclofop-methyl (4 MBq mg ${ }^{-1}$, 1,4-dioxypheyl ring labeled, 98\% chemical purity). Herbicides were applied at $800 \mathrm{~g} \mathrm{ha}^{-1}$ as previously described, and nonlabeled herbicides were added in treatment solutions at $4 \mu \mathrm{g}$ ai $\mu \mathrm{l}^{-1}$. Plants were harvested at 24, 48 , or 96 HAT, and metabolism was quantified using the aforementioned procedures. The stock solutions of ${ }^{14} \mathrm{C}$-diclofop-methyl and ${ }^{14} \mathrm{C}$-metamifop were run in separate lanes on TLC plates for comparison to the parent herbicides. Diclofop acid (99\% chemical purity, Chem Service Inc., West Chester, PA 
19381) was dissolved in acetone and spotted on plates as previously described to identify the retention factor $\left(\mathrm{R}_{\mathrm{f}}\right)$ with a fluorescent indicator.

ACCase Enzyme Assay. The susceptibility of isolated ACCase enzymes to inhibition by metamifop was evaluated using a methodology modified from previous research (Kuk et al. 1999; Seefeldt et al. 1996; Yang et al. 2007). All products used for analysis were purchased from Sigma-Aldrich (St. Louis, MO 63103) unless otherwise noted. Fresh leaf tissue (3 g) was sampled from creeping bentgrass, goosegrass, and Kentucky bluegrass. Leaves were pulverized in liquid nitrogen using a mortar and pestle. Samples were extracted in $15 \mathrm{ml}$ of the buffer solution consisting of $100 \mathrm{mM}$ Tris ( $\mathrm{pH} 8.0), 1 \mathrm{mM}$ EDTA, $10 \%$ glycerol, $2 \mathrm{mM}$ isoascorbic acid, $0.5 \%$ polyvinylpolypyrrolidone (PVP)- $40,0.5 \%$ insoluble PVP, $20 \mathrm{mM}$ dithiothreitol (DTT), and $0.2 \mathrm{mM}$ phenylmethylsulfonyl fluoride. Samples were homogenized, filtered with double layers of Miracloth (EMD Millipore Corporation, Billerica, MA 01821), and then centrifuged (Beckman J2-MI Model, Beckman Instruments, 2500 Harbor Boulevard, Fullerton, CA 92634) at 27,000 $\times g$ for $30 \mathrm{~min}$. The supernatant was decanted, transferred to new tubes, and then adjusted to $40 \%$ ammonium sulfate saturation. Tubes were kept on ice bath under stirring for $30 \mathrm{~min}$ for protein precipitation and then centrifuged again at $27,000 \times g$ for $30 \mathrm{~min}$. The pellet (including precipitated protein) was resuspended in $2 \mathrm{ml}$ of elution buffer including 50 $\mathrm{mM}$ tricine $\left(\mathrm{pH}\right.$ 8), $2.5 \mathrm{mM} \mathrm{MgCl}_{2} \cdot 6 \mathrm{H}_{2} \mathrm{O}$, $50 \mathrm{mM} \mathrm{KCl}, 1.0 \mathrm{mM}$ DTT. The protein extract was then desalted using a Sephadex G-25 column equilibrated with elution buffer.

A 40- $\mu$ l aliquot of the enzyme solution was then incubated at $32 \mathrm{C}$ for $3 \mathrm{~min}$ in a medium solution containing $20 \mathrm{mM}$ Tricine- $\mathrm{KOH}$ (pH 8.3), $10 \mathrm{mM}$ $\mathrm{KCl}, 5 \mathrm{mM}$ adenosine triphosphate, $2 \mathrm{mM} \mathrm{MgCl}_{2}$, $0.2 \mathrm{mg}(\mathrm{wt} / \mathrm{v})$ bovine serum albumin (fatty acid free), $2.5 \mathrm{mM}$ DTT, $3.7 \mathrm{mM} \mathrm{NaHCO} 3$ including 1 $\mu \mathrm{Ci}$ of $\mathrm{NaH}^{14} \mathrm{CO}_{3}\left(55 \mathrm{mCi} \mathrm{mmol}^{-1}\right.$; American Radiolabeled Chemicals Inc.; St. Louis, MO). This medium solution also contained $0,0.1,1,10$, or $100 \mu \mathrm{M}$ of technical-grade metamifop (99\% chemical purity, Chem Service Inc.). The reaction was initiated by adding acetyl-CoA (lithium salt) to a final concentration of $0.25 \mathrm{mM}$ in a final volume of reaction mixture of $200 \mu \mathrm{l}$. The sample was incubated at $32 \mathrm{C}$ under a fume hood for $30 \mathrm{~min}$. All reagents except acetyl-CoA were added in a 7-ml centrifuge tube and preincubated for $3 \mathrm{~min}$ at $32 \mathrm{C}$ under a fume hood.
Background ${ }^{14} \mathrm{C}$-fixation (nonenzymatic ${ }^{14} \mathrm{CO}_{2}$ fixation) was determined by substituting degassed, deionized water for acetyl-CoA. After the reaction termination, the radioactivity fixed to malonyl-CoA was quantified by liquid scintillation spectroscopy. The concentration of herbicide required to cause $50 \%$ inhibition of ACCase activity $\left(\mathrm{I}_{50}\right)$ was determined from concentration response curves.

In separate experiments, the susceptibility of isolated ACCase enzymes of bermudagrass to inhibition by diclofop acid and metamifop was evaluated using the aforementioned methodology. Concentrations of the medium solutions evaluated contained $0.1,1$, 10 , or $100 \mu \mathrm{M}$ of either herbicide. Radioactivity fixed to malonyl-CoA was quantified as previously described, and $\mathrm{I}_{50}$ values were determined from the concentration-response curves.

Experimental Design and Data Analysis. Greenhouse experiments were conducted as a randomized complete block design with four replications. Blocks were used to account for potential variability within greenhouse location on plant responses to treatments. The greenhouse experiment with creeping bentgrass, goosegrass, and Kentucky bluegrass was repeated once. The bermudagrass greenhouse experiment was repeated twice. Absorption and metabolism experiments were conducted as completely randomized designs with five replications, and the experiments were repeated once and twice, respectively. The ACCase enzyme assay was conducted as a randomized complete block with four replications, and the experiment was repeated once. This design was chosen to block for potential daily variability in laboratory conditions because of the amount of time required to run one replication of the assay.

Data were subjected to analysis of variance with the General Linear Model procedure in SAS (v. 9.4, Cary, NC) to evaluate species by run interaction. Injury, shoot biomass, and absorption were then subjected to regression analysis with the Nonlinear Regression procedure in SAS. Data were regressed with the following two-parameter growth function equation:

$$
y=\beta_{0}\left\{1-\left[\exp \left(-\beta_{1} x\right)\right]\right\},
$$

where $y$ is plant response, $\beta_{0}$ is the asymptote, $\beta_{1}$ is the slope estimate, and $x$ is herbicide rate or hour after treatment. Benchmark values for plant responses were calculated from regression analysis to facilitate discussion of the results. The $95 \%$ confidence limit for these values was calculated in 


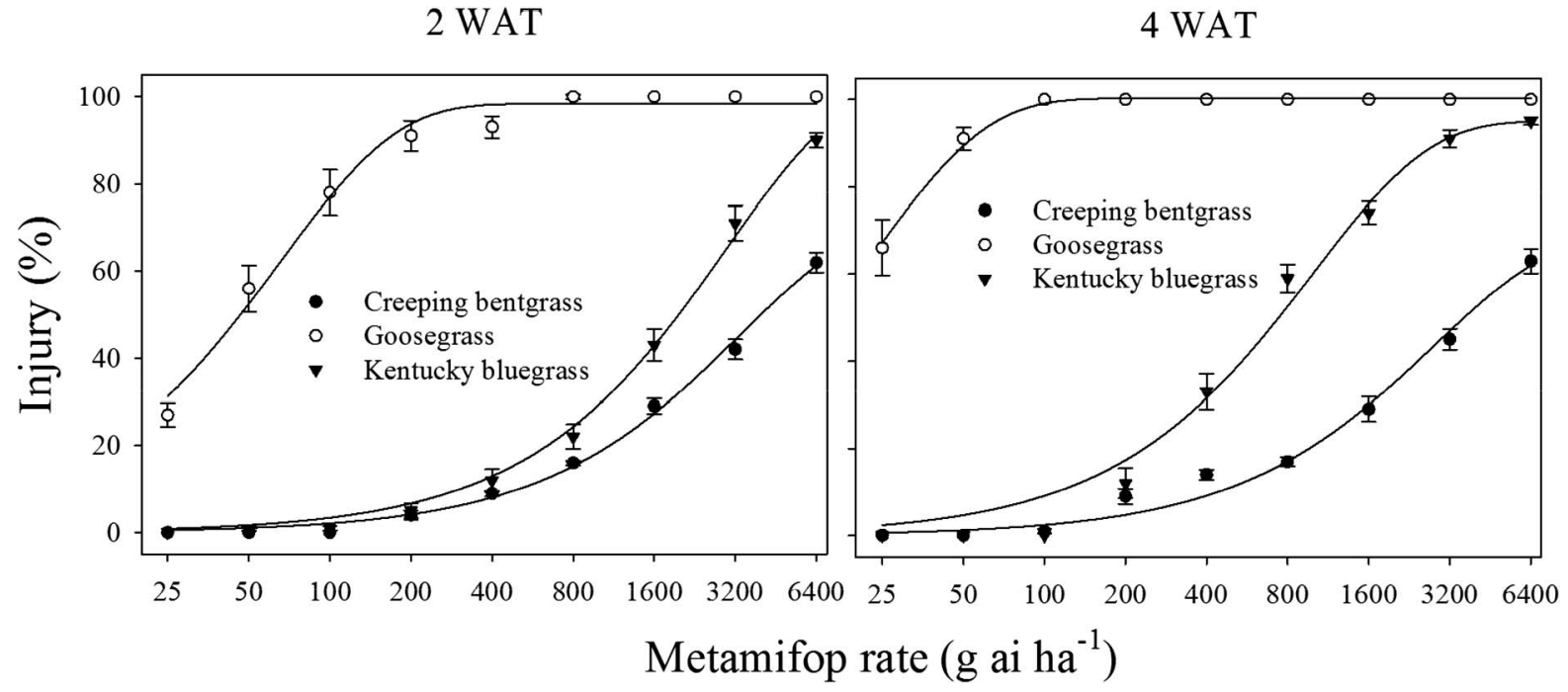

Figure 1. Injury of Penn A-4 creeping bentgrass, goosegrass, and Midnight Kentucky bluegrass after metamifop applications in two experiments, 2014-2015, in Griffin, GA. Results were pooled over experimental runs. WAT = weeks after treatment. Vertical bars represent standard errors of the mean $(n=8)$. Data were regressed with the following equation: $y=\beta_{0}\left\{1-\left[\exp \left(-\beta_{1} x\right)\right]\right\}$, where $y$ is injury, $\beta_{0}$ is the asymptote, $\beta_{1}$ is the slope estimate, and $x$ is metamifop rate. Creeping bentgrass regression at 2 WAT: $y=74.41$ $\{1-[\exp (-0.0003 x)]\}$. Creeping bentgrass regression at 4 WAT: $y=69.3\{1-[\exp (-0.0003 x)]\}$. Goosegrass regression at 2 WAT: $y=98.3\{1-[\exp (-0.015 x)]\}$. Goosegrass regression at 4 WAT: $y=100.3\{1-[\exp (-0.044 x)]\}$. Kentucky bluegrass regression at 2 WAT: $y=103.7\{1-[\exp (-0.0003 x)]\}$. Kentucky bluegrass regression at 4 WAT: $y=94.6[1-[\exp (-0.001 x)]\}$.

SigmaPlot (v. 11.2, Systat Software Inc., San Jose, $\mathrm{CA}$ ) with the aforementioned two-parameter regression analysis (Table 1). For metabolism evaluations, means were separated with Fisher's LSD test at $\alpha=0.05$. Contrast statements were used for further comparisons of species on ACCase inhibition by metamifop. Experimental run by species and run by herbicide interactions were not detected; thus, results were pooled over runs.

\section{Results and Discussion}

Injury and Shoot Mass Reductions. Species by metamifop rate interactions were detected for injury and shoot biomass reductions from the nontreated. Thus, results are presented across all possible combinations. Injury was expressed as tissue chlorosis and stunted growth. The metamifop rate required to injure goosegrass $90 \%$ and turfgrasses $20 \%$ from regression analyses are discussed. These levels indicate benchmarks for goosegrass control and acceptable injury to intensively managed turfgrass, respectively.

Creeping bentgrass and Kentucky bluegrass exhibited a substantially greater tolerance to metamifop than goosegrass. The metamifop rate required to injure goosegrass $90 \%$ at 2 and 4 WAT measured 165 and $52 \mathrm{~g} \mathrm{ha}^{-1}$, respectively (Figure 1; Table 1). Conversely, application rates of $\sim 800 \mathrm{~g} \mathrm{ha}^{-1}$ caused $<20 \%$ injury to creeping bentgrass and Kentucky bluegrass at 2 WAT. At 4 WAT, creeping bentgrass was injured $<20 \%$ from metamifop at $\leq 800 \mathrm{~g}$ $\mathrm{ha}^{-1}$. Kentucky bluegrass was injured $<20 \%$ from metamifop at $\leq 200 \mathrm{~g} \mathrm{ha}^{-1}$, but rates $>400 \mathrm{~g} \mathrm{ha}^{-1}$ caused $>35 \%$ injury. The metamifop rate required to reduce shoot biomass $50 \%$ from the nontreated $\left(\mathrm{GR}_{50}\right)$ at $4 \mathrm{WAT}$ was $>6,400,2,166$, and $53 \mathrm{~g}$ ai $\mathrm{ha}^{-1}$ for creeping bentgrass, Kentucky bluegrass, and goosegrass, respectively (Figure 2; Table 1).

Turfgrass tolerance levels to metamifop are comparable to previous field experiments. Hart and Mansue (2010) reported creeping bentgrass and Kentucky bluegrass were injured $\leq 15 \%$ from metamifop at $800 \mathrm{~g} \mathrm{ha}^{-1}$. Flessner and McElroy (2011) reported these grasses also had minimal injury from metamifop applied singly or sequentially in summer. Goosegrass had more injury from metamifop than creeping bentgrass and Kentucky bluegrass, and the differential tolerance levels are consistent with previous research (Hart and Mansue 2010). Creeping bentgrass had less injury from metamifop than Kentucky bluegrass in these greenhouse experiments. However, grasses were not clipped for 4 wk and the influence of mowing height or frequency could influence relative injury levels in the field. Further research is needed to evaluate the effects of cultural practices on turfgrass injury potential with metamifop and efficacy for goosegrass control.

Herbicide by rate interactions were detected for bermudagrass injury and shoot biomass reductions. Bermudagrass $\mathrm{I}_{50}$ values from diclofop-methyl 


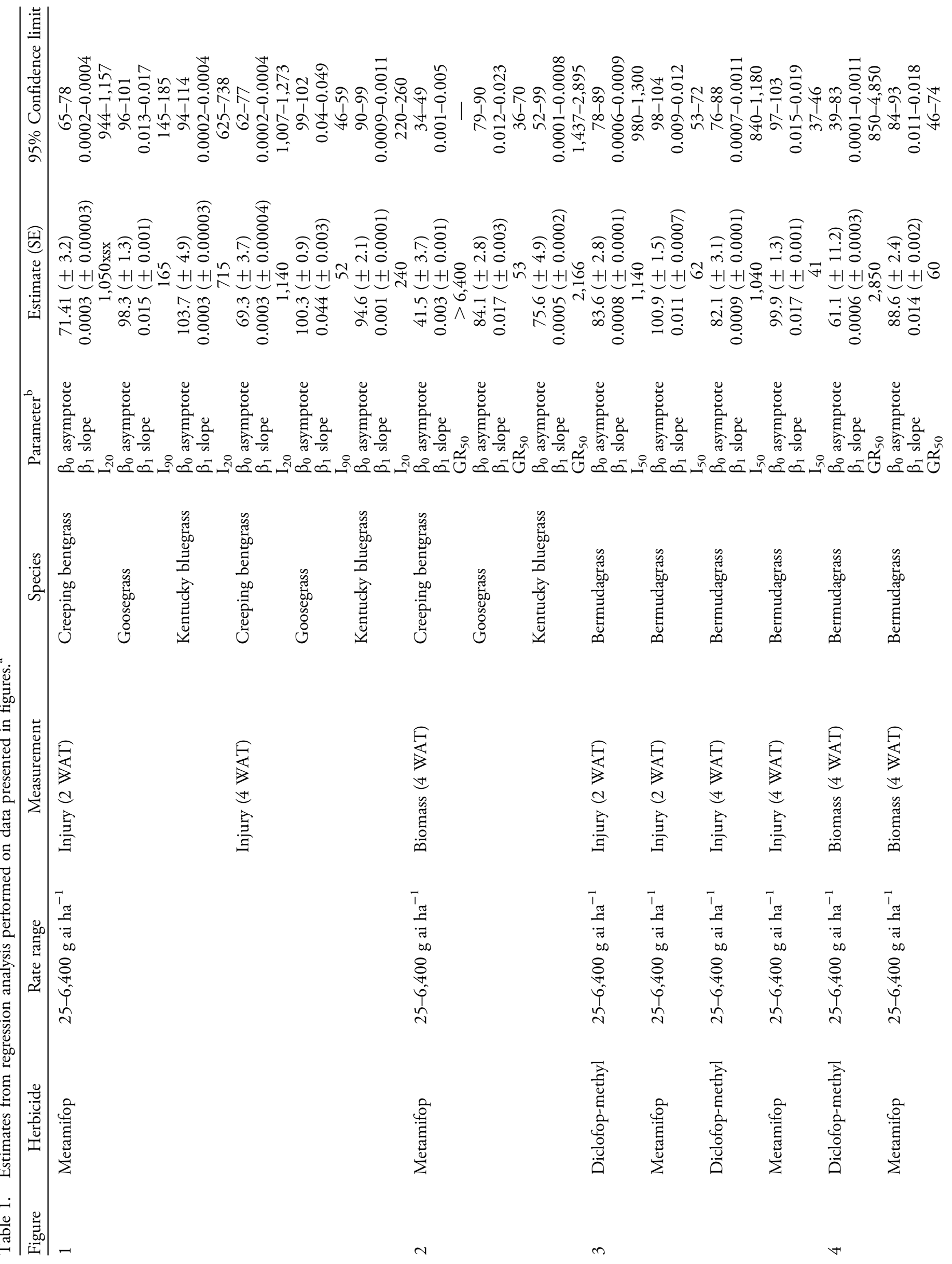




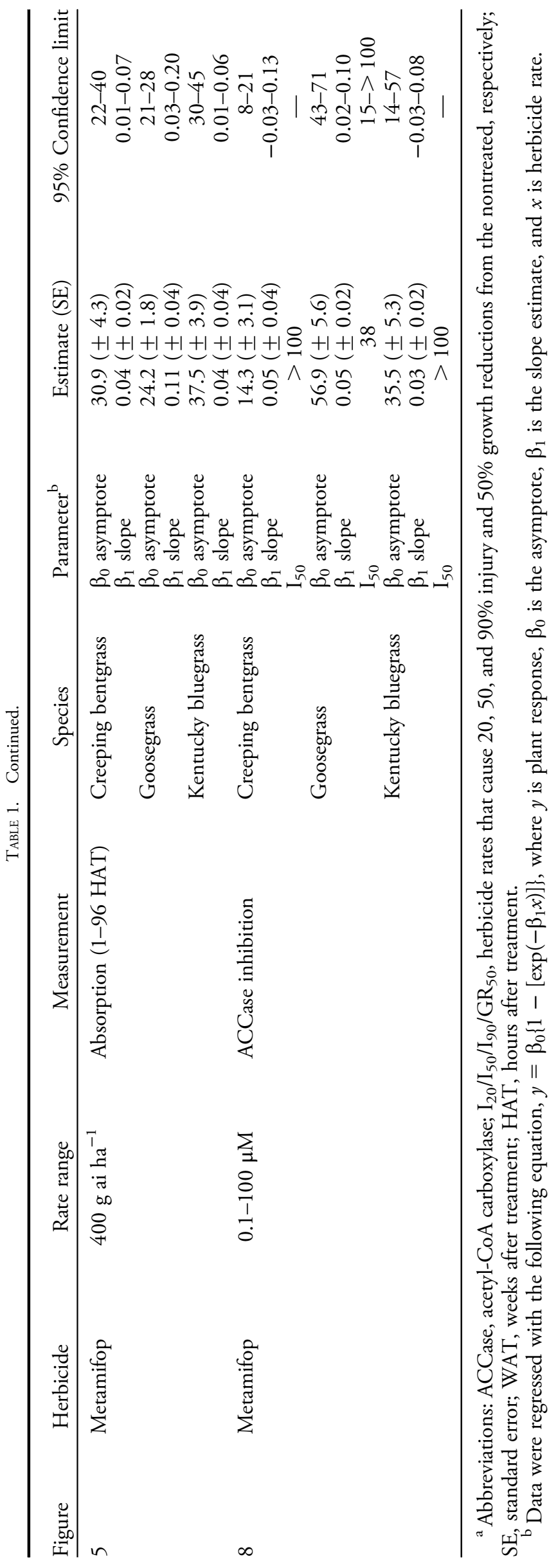

measured 1,140 and 1,040 $\mathrm{g} \mathrm{ha}^{-1}$ at 2 and 4 WAT, respectively (Figure 3; Table 1). Conversely, bermudagrass $I_{50}$ values from metamifop were 62 and $41 \mathrm{~g}$ $\mathrm{ha}^{-1}$ at 2 and 4 WAT, respectively. The $\mathrm{GR}_{50}$ for bermudagrass treated with diclofop-methyl or metamifop was 2,850 and $60 \mathrm{~g} \mathrm{ha}^{-1}$, respectively (Figure 4; Table 1).

The susceptibility of bermudagrass to metamifop was $\sim 20$ times greater than diclofop-methyl. These levels of injury are consistent with previous field research on metamifop efficacy for bermudagrass control (Doroh et al. 2011). Diclofop-methyl is the least injurious ACCase inhibitor on bermudagrass, and applications may selectively control goosegrass in turfgrass systems (McCarty 1991). McCarty et al. (1991) reported that diclofop-methyl rates $\geqslant 3.4 \mathrm{~kg}$ $\mathrm{ha}^{-1}$ were required to induce excessive injury ( $>20 \%)$ to bermudagrass turf. Single plants of bermudagrass appeared to be more injured from diclofop-methyl under greenhouse condition than previous reports in field experiments (McCarty 1991; McCarty et al. 1991). Nevertheless, the application rates of these two herbicides are comparable for goosegrass control, and bermudagrass has much greater injury potential from metamifop than diclofop-methyl. In other experiments, injury from diclofop-methyl varied among bermudagrass cultivars, suggesting genetic variability within a species could contribute to differential tolerance to ACCase inhibitors (McCarty et al. 1991). Genetic variability between common $C$. dactylon and hybrid $C$. dactylon $\times C$. transvaalensis varieties may also influence the efficacy of metamifop for bermudagrass control and warrants further investigation.

Absorption and Translocation. Peak absorption of ${ }^{14} \mathrm{C}$-metamifop was reached at 48, 72, and 96 HAT for goosegrass, creeping bentgrass, and Kentucky bluegrass, respectively (Figure 5). The asymptotic level of uptake was 24, 31, and 38\% of the applied ${ }^{14} \mathrm{C}$-metamifop for goosegrass, creeping bentgrass, and Kentucky bluegrass, respectively. Goosegrass had faster foliar uptake of metamifop than turfgrasses, but the tolerant species absorbed more herbicide over time. Metamifop absorption could have been inhibited in goosegrass after $48 \mathrm{~h}$ because of greater phytotoxicity than turfgrasses that continued absorbing the herbicide.

All species translocated $<10 \%$ of the absorbed radioactivity out of the treated leaf at 96 HAT. Creeping bentgrass translocated $9 \%$ of the absorbed radioactivity to nontreated shoots, which was three times greater than goosegrass and Kentucky 


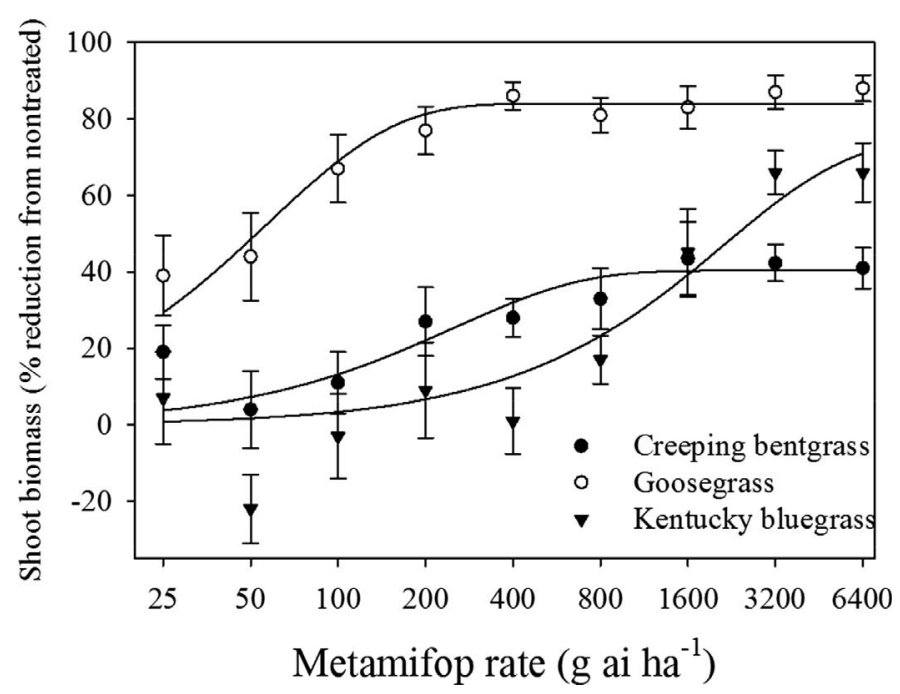

Figure 2. Shoot biomass reduction from the nontreated for Penn A-4 creeping bentgrass, goosegrass, and Midnight Kentucky bluegrass at $4 \mathrm{wk}$ after metamifop treatments in two experiments, 2014-2015, in Griffin, GA. Results were pooled over experimental runs. Vertical bars represent standard errors of the mean $(n=8)$. Data were regressed with the following equation: $y=$ $\beta_{0}\left\{1-\left[\exp \left(-\beta_{1} x\right)\right]\right\}$, where $y$ is shoot biomass reductions, $\beta_{0}$ is the asymptote, $\beta_{1}$ is the slope estimate, and $x$ is metamifop rate. Creeping bentgrass regression: $y=41.5\{1-[\exp (-0.003 x)]\}$. Goosegrass regression: $y=84.1\{1-[\exp (-0.017 x)]\}$. Kentucky bluegrass regression: $y=75.6\{1-[\exp (-0.0005 x)]\}$.

bluegrass (data not shown). Less than $0.5 \%$ of the absorbed radioactivity was recovered in roots of all species. Kim et al. (2003) determined that barnyardgrass [Echinochloa crus-galli (L.) Beauv.] and rice had similar radioactivity translocation at 72 HAT with ${ }^{14} \mathrm{C}$-metamifop. However, barnyardgrass absorbed $\sim 27 \%$ more ${ }^{14} \mathrm{C}$-metamifop than a tolerant species, rice.

Species by harvest interaction was not detected for recovery of the applied radioactivity. Radioactivity recovery linearly declined from 1 to 96 HAT and ranged 87 to $66 \%$ of the applied ${ }^{14} \mathrm{C}$ (data not shown). Differences among species were not detected for recovery of the applied radioactivity. Results suggest that volatilization may contribute to metamifop losses similar to other ACCase inhibitors. Chandrasena and Sagar (1986) recovered only 66\% of the applied ${ }^{14} \mathrm{C}$-fluazifop at 24 HAT with various adjuvants on quackgrass [Elymus repens (L.) Gould]. Grafstron and Nalewaja (1988) reported that ${ }^{14} \mathrm{C}$ fluazifop recovery measured $65 \%$ at 96 HAT to green foxtail [Setaria viridis (L.) Beauv.], but recovery increased to $82 \%$ when applied with petroleum oil. Spray retention of graminicides is often critical for enhancing uptake of herbicides in turfgrass by frequent mowing operations.

The role of absorption on metamifop selectivity may differ between turfgrasses and rice. The selectivity of ACCase inhibitors is typically not associated with absorption or translocation between tolerant and susceptible plants (DePrado et al. 2005; Kuk et al. 1999; Tardif et al. 1996). The substantial differences in injury between goosegrass and turfgrasses
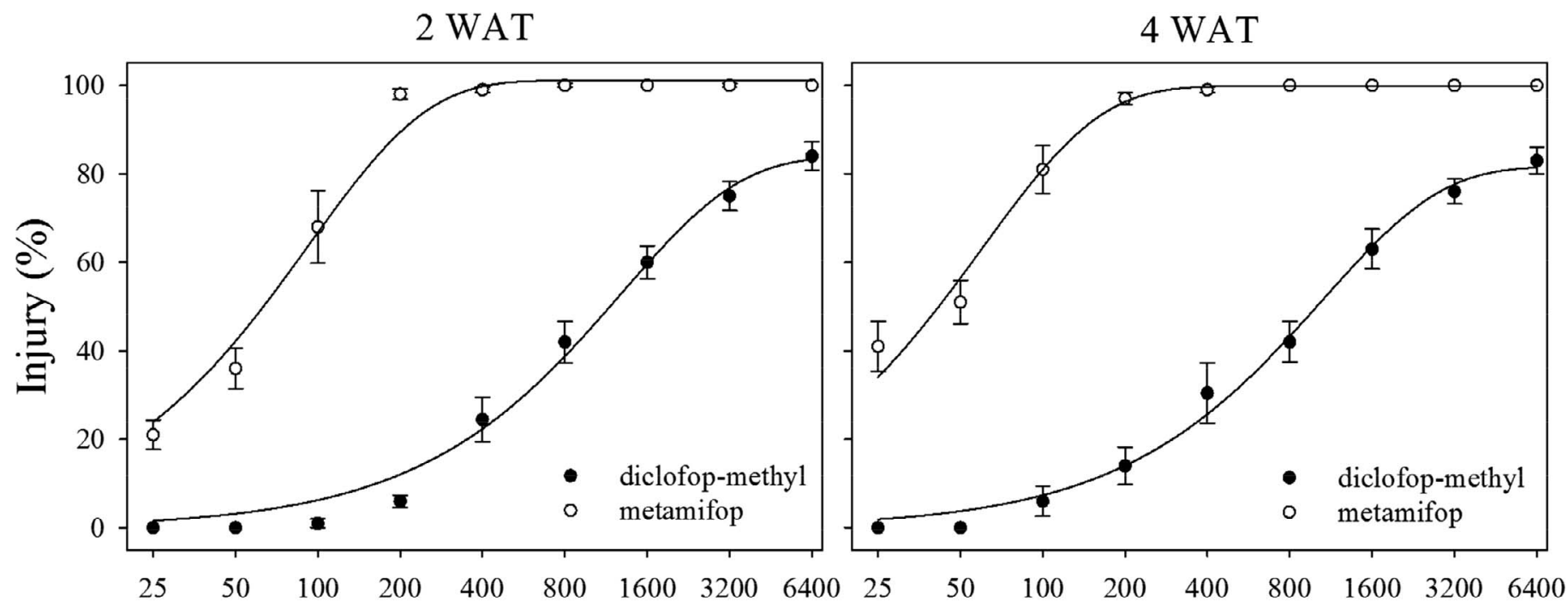

Application rate (g ai ha ${ }^{-1}$ )

Figure 3. Injury of Princess-77 bermudagrass following treatments with diclofop-methyl or metamifop in three experiments, 20142015, in Griffin, GA. Results were pooled over experimental runs. WAT = weeks after treatment. Vertical bars represent standard errors of the mean $(n=12)$. Data were regressed with the following equation: $y=\beta_{0}\left\{1-\left[\exp \left(-\beta_{1} x\right)\right]\right\}$, where $y$ is injury, $\beta_{0}$ is the asymptote, $\beta_{1}$ is the slope estimate, and $x$ is herbicide rate. Diclofop-methyl regression at 2 WAT: $y=83.6\{1-[\exp (-0.0008 x)]\}$. Diclofop-methyl regression at 4 WAT: $y=82.1\{1-[\exp (-0.0009 x)]\}$. Metamifop regression at 2 WAT: $y=100.9\{1-[\exp (-0.011 x)]\}$. Metamifop regression at 4 WAT: $y=99.9\{1-[\exp (-0.017 x)]\}$. 


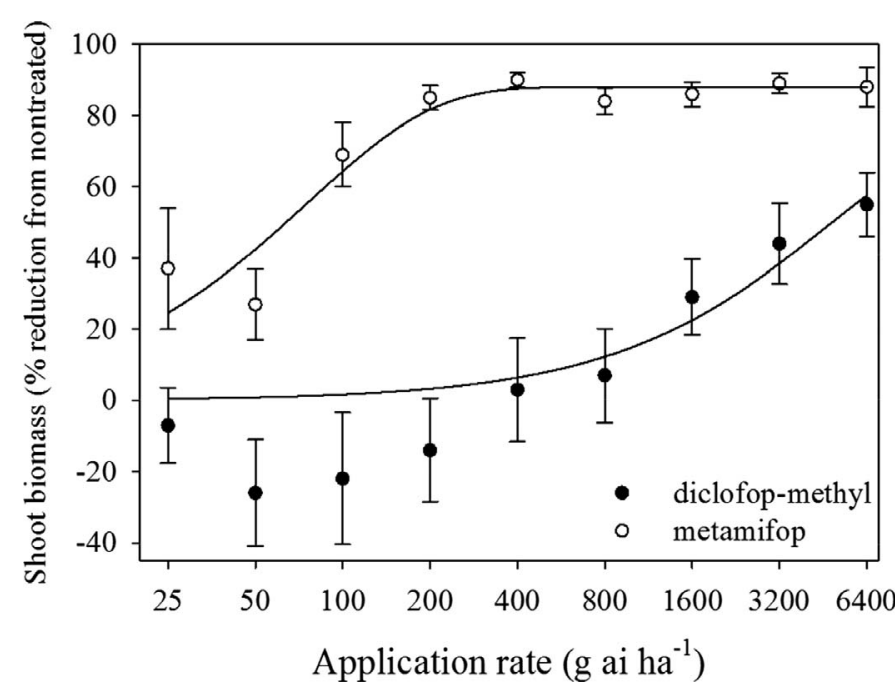

Figure 4. Shoot biomass reductions from the nontreated for Princess-77 bermudagrass at $4 \mathrm{wk}$ after treatment (WAT) with diclofop-methyl or metamifop in three experiments, 2014-2015, in Griffin, GA. Results were pooled over experimental runs. Vertical bars represent standard errors of the mean $(n=12)$. Data were regressed with the following equation: $y=\beta_{0}\{1-[\exp$ $\left.\left.\left(-\beta_{1} x\right)\right]\right\}$, where $y$ is shoot biomass reductions, $\beta_{0}$ is the asymptote, $\beta_{1}$ is the slope estimate, and $x$ is herbicide rate. Diclofop-methyl regression: $y=61.1\{1-[\exp (-0.0006 x)]\}$. Metamifop regression: $y=88.6\{1-[\exp (-0.014 x)]\}$.

are not explained by total herbicide uptake. Nevertheless, creeping bentgrass and Kentucky bluegrass had more absorption than goosegrass, suggesting other physiological mechanisms are associated with the selectivity of metamifop.

Metabolism. Species by harvest interaction was not detected for parent herbicide recovery. Thus results were pooled over main effects (Table 2). Extraction efficiency averaged $87 \%$ ( \pm 0.9 standard error of the mean [SEM]) of the absorbed radioactivity (data not shown). The peak for ${ }^{14} \mathrm{C}$-metamifop was detected at $\mathrm{R}_{\mathrm{f}} 0.5$, whereas two metabolites were detected at $R_{f} 0.05$ and 0.45 (Figure 6). The degradation of metamifop to polar conjugates increased from 48 to 96 HAT. Goosegrass metabolized ${ }^{14} \mathrm{C}$ metamifop only $25 \%$, which was greater than that measured within creeping bentgrass and Kentucky bluegrass (15\%). The metabolite detected at $R_{f}$ 0.45 was recovered at $\sim 2$-times greater concentrations in goosegrass than the turfgrasses. Results suggest detoxification of metamifop through metabolism likely does not contribute to selectivity in these species.

The role of metabolism on ACCase inhibitor selectivity is variable across species. Shukla et al. (1997) reported that an ACCase-resistant biotype of wild oat (Avena fatua L.) had similar metabolism

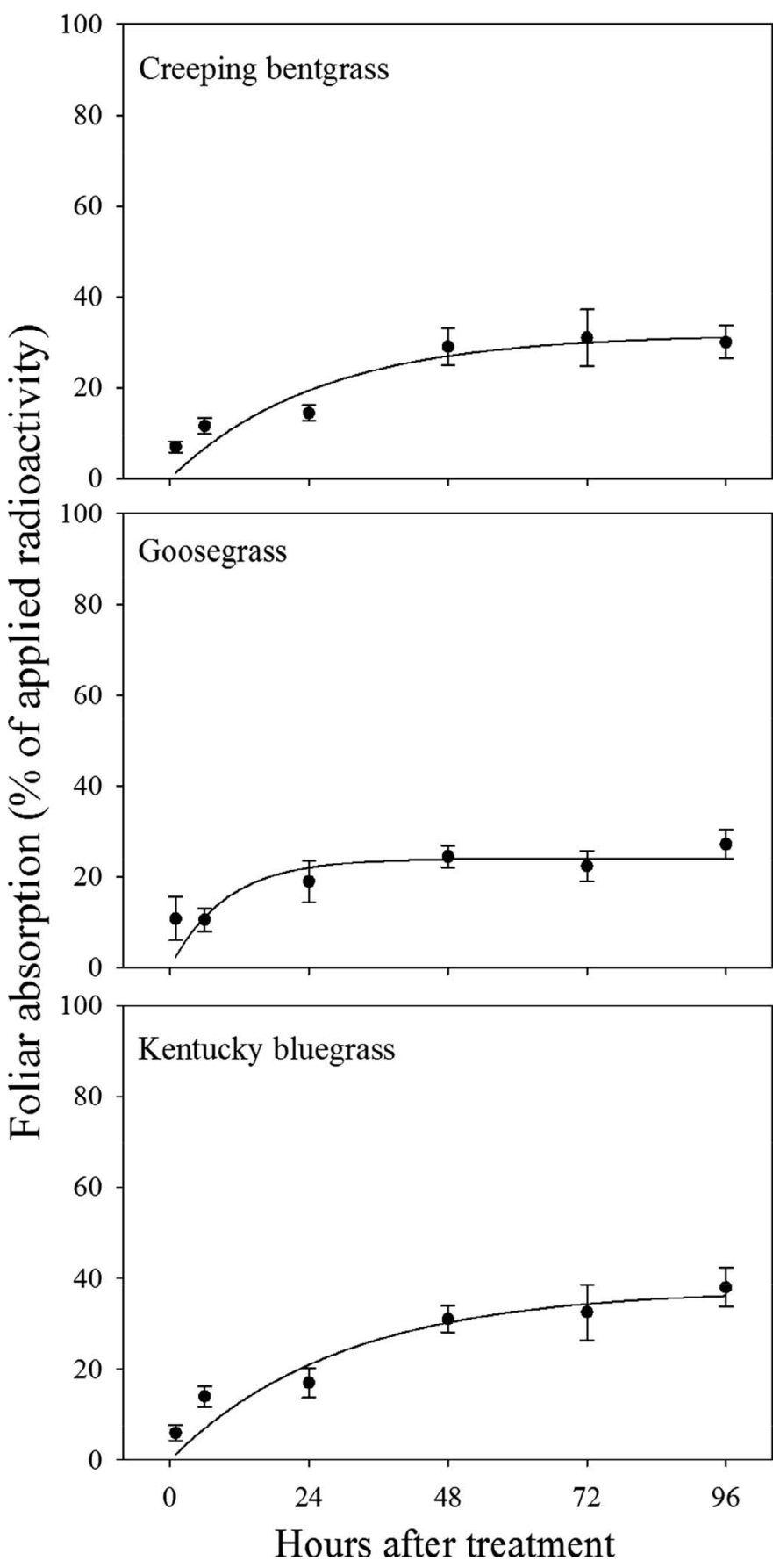

Figure 5. Foliar absorption of ${ }^{14} \mathrm{C}$-metamifop in Penn A-4 creeping bentgrass, goosegrass, and Midnight Kentucky bluegrass in two laboratory experiments, 2014, in Griffin, GA. Results were pooled over experimental runs. Vertical bars represent standard errors of the mean $(n=10)$. Data were regressed with the following equation: $y=\beta_{0}\left\{1-\left[\exp \left(-\beta_{1} x\right)\right]\right\}$, where $y$ is absorption, $\beta_{0}$ is the asymptote, $\beta_{1}$ is the slope estimate, and $x$ is hours after treatment. Creeping bentgrass regression: $y=30.9\{1-[\exp (-0.04 x)]\}$. Goosegrass regression: $y=24.2\{1-[\exp (-0.11 x)]\}$. Kentucky bluegrass regression: $y=37.5\{1-[\exp (-0.04 x)]\}$.

of fenoxaprop and diclofop to a susceptible biotype. Tardif et al. (1996) reported no differences in metabolism of diclofop-methyl or haloxyfop-methyl between the resistant and susceptible biotypes of 
Table 2. Metabolism of ${ }^{14}$ C-metamifop in Penn A-4 creeping bentgrass, goosegrass, and Midnight Kentucky bluegrass in three experiments. Results were pooled over experimental runs. ${ }^{\text {a }}$

\begin{tabular}{|c|c|c|c|}
\hline \multirow[b]{2}{*}{ Species } & \multirow{2}{*}{$\frac{\text { Metamifop }}{\mathrm{R}_{\mathrm{f}} 0.5}$} & \multicolumn{2}{|c|}{ Metabolites } \\
\hline & & $\mathrm{R}_{\mathrm{f}} 0.05$ & $\mathrm{R}_{\mathrm{f}} 0.45$ \\
\hline & \multicolumn{3}{|c|}{$\%$ of ${ }^{14} \mathrm{C}$ extracted } \\
\hline Creeping bentgrass & 84 & 12 & 4 \\
\hline Goosegrass & 75 & 17 & 8 \\
\hline Kentucky bluegrass & 86 & 11 & 3 \\
\hline $\mathrm{LSD}_{0.05}$ & 4 & 4 & 3 \\
\hline \multicolumn{4}{|l|}{ Harvest (HAT) } \\
\hline 24 & 84 & 9 & 7 \\
\hline 48 & 84 & 12 & 4 \\
\hline 96 & 76 & 20 & 4 \\
\hline $\mathrm{LSD}_{0.05}$ & 4 & 4 & 3 \\
\hline Species & $*$ & $*$ & $*$ \\
\hline Harvest & $*$ & $*$ & $*$ \\
\hline Species $\times$ harvest & NS & NS & NS \\
\hline
\end{tabular}

${ }^{a}$ Abbreviations: $R_{f}$, retention factor; HAT, hours after treatment.

* Significant at the $\mathrm{P}=0.05$ probability level.

rigid ryegrass. Kuk et al. (1999) determined that the metabolism of fenoxaprop was similar in resistant and susceptible biotypes of smooth crabgrass [Digitaria ischaemum (Schreb.) Schreb. ex Muhl.].

Harvest by herbicide interaction was not detected for bermudagrass absorption or metabolism; thus, results were pooled over main effects. Bermudagrass absorption of ${ }^{14} \mathrm{C}$-metamifop was similar to ${ }^{14} \mathrm{C}$-diclofop-methyl and averaged $38 \%( \pm 2.1$ SEM) of the applied radioactivity (data not shown). Peak absorption was reached after $24 \mathrm{~h}$ for both herbicides. The level of metamifop metabolism in bermudagrass was comparable to creeping bentgrass and Kentucky bluegrass (Table 3). Bermudagrass metabolized only $14 \%$ of the ${ }^{14} \mathrm{C}$-metamifop, and metabolite formation was similar to tolerant turfgrasses (Figure 7). Conversely, bermudagrass metabolism of diclofop-methyl increased linearly over

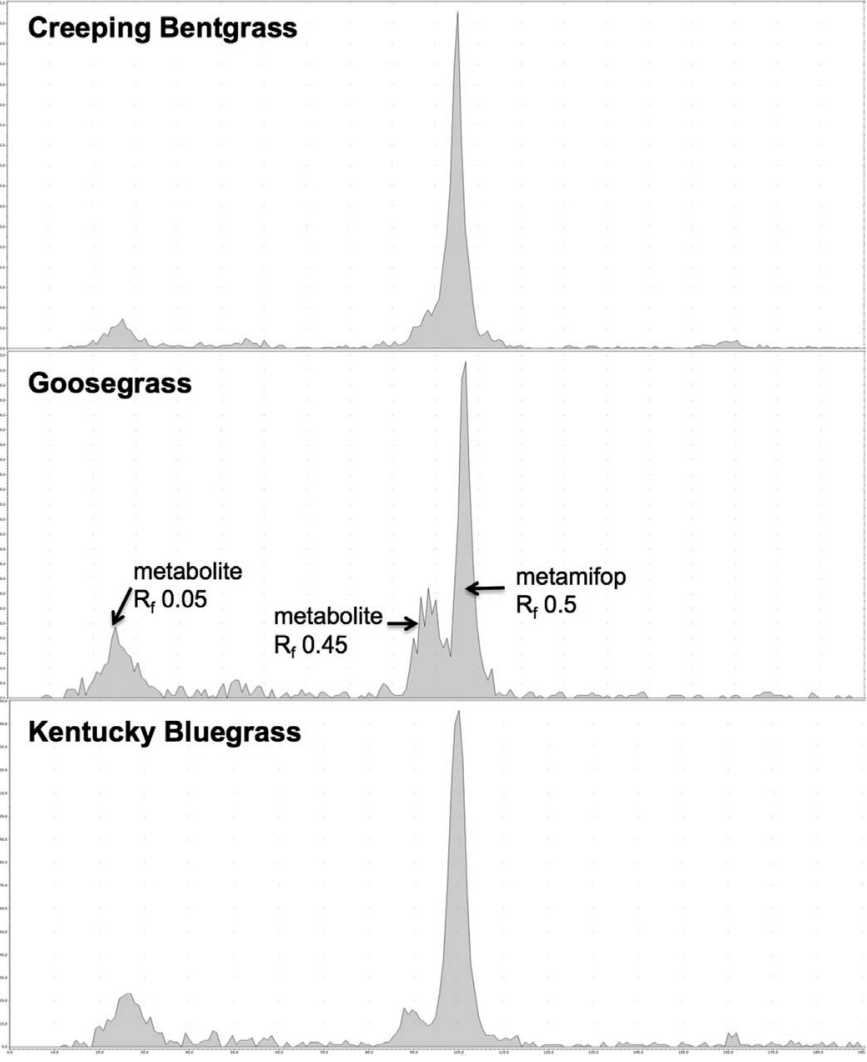

Figure 6. Radiochromatograph scan of metamifop metabolites at 48 hours after treatment in Penn A-4 creeping bentgrass, goosegrass, and Midnight Kentucky bluegrass. (Color for this figure is available in the online version of this article.)

time. At 96 HAT, 23 and $60 \%$ of the absorbed ${ }^{14} \mathrm{C}$-diclofop-methyl was metabolized to diclofop acid and a polar conjugate, respectively.

The tolerance of bermudagrass to diclofop-methyl may be associated with faster metabolism than metamifop. Mendez and De Prado (1996) reported that a resistant biotype of blackgrass (Alopecurus myosuroides Huds.) metabolized twice as much diclofop-methyl than a susceptible biotype after $72 \mathrm{~h}$. Shimabukuro et al. (1979) proved the tolerance of wheat (Triticum

Table 3. Metabolism of ${ }^{14} \mathrm{C}$-diclofop-methyl and ${ }^{14} \mathrm{C}$-metamifop in Princess-77 hybrid bermudagrass in two experiments. Results were pooled over experimental runs. ${ }^{\text {a }}$

\begin{tabular}{|c|c|c|c|c|c|}
\hline \multirow[b]{2}{*}{ Harvest } & \multicolumn{3}{|c|}{ Diclofop-methyl metabolites } & \multicolumn{2}{|c|}{ Metamifop metabolites } \\
\hline & $\begin{array}{l}\text { Metabolite } \\
\left(\mathrm{R}_{\mathrm{f}} 0.05\right)\end{array}$ & $\begin{array}{c}\text { Diclofop acid } \\
\left(\mathrm{R}_{\mathrm{f}} 0.5\right)\end{array}$ & $\begin{array}{l}\text { Diclofop-methyl } \\
\left(\mathrm{R}_{\mathrm{f}} 0.7\right)\end{array}$ & $\begin{array}{c}\text { Metabolites }\left(\mathrm{R}_{\mathrm{f}} 0.05\right. \\
+0.45) \\
\end{array}$ & $\begin{array}{l}\text { Metamifop } \\
\left(\mathrm{R}_{\mathrm{f}} 0.5\right)\end{array}$ \\
\hline HAT & & & - $\%$ of ${ }^{14} \mathrm{C}$ extract & & \\
\hline 24 & $26( \pm 4)^{\mathrm{b}}$ & $46( \pm 4)$ & $28( \pm 3)$ & $12( \pm 3)$ & $88( \pm 3)$ \\
\hline 48 & $50( \pm 6)$ & $32( \pm 4)$ & $18( \pm 4)$ & $13( \pm 2)$ & $87( \pm 3)$ \\
\hline 96 & $60( \pm 5)$ & $23( \pm 3)$ & $17( \pm 3)$ & $14( \pm 3)$ & $86( \pm 3)$ \\
\hline Linear & * & * & NS & NS & NS \\
\hline Quadratic & NS & NS & NS & NS & NS \\
\hline
\end{tabular}

${ }^{a}$ Abbreviations: $\mathrm{R}_{\mathrm{f}}$, retention factor; HAT, hours after treatment.

${ }^{\mathrm{b}}$ Numbers in parentheses are standard errors of the mean $(n=8)$.

* Significant at the $\mathrm{P}=0.05$ probability level. 


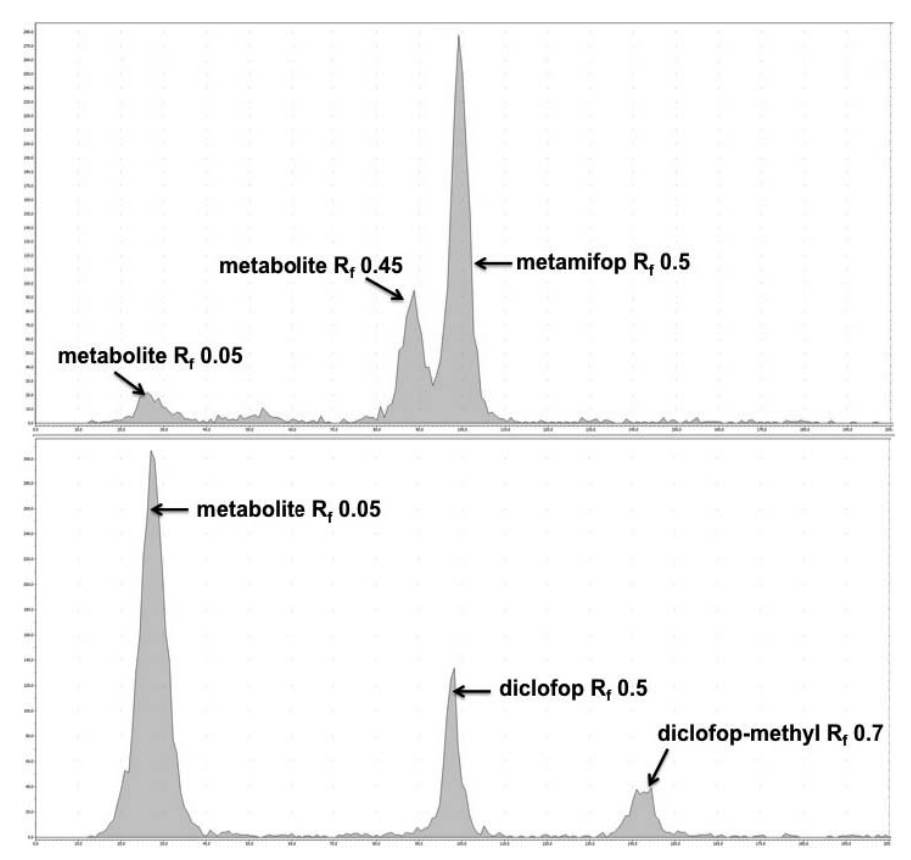

Figure 7. Radiochromatograph scan of metabolites of diclofopmethyl and metamifop in Princess-77 bermudagrass at $96 \mathrm{~h}$ after treatment. (Color for this figure is available in the online version of this article.)

aestivum L.) to diclofop-methyl was due to the aryl hydroxylation. It was also noted that a more susceptible species, wild oat, conjugated diclofop to a neutral glycosyl ester, suggesting differential metabolism was the primary mechanism for selectivity. Similar differences in metabolism were associated with the selectivity of cyhalofop-butyl for early watergrass [Echinochloa oryzoides (Ard.) Fritsch] control in rice (Ruiz-Santaella et al. 2006).

The metabolism of ACCase inhibitors has received limited investigation in turfgrasses. Tolerant turfgrasses had higher levels of the parent herbicide than goosegrass, suggesting the selectivity of metamifop cannot be directly attributed to detoxification through metabolism. The metabolite at $\mathrm{R}_{\mathrm{f}} 0.45$ was measured in higher concentrations in goosegrass than turfgrasses and may be noteworthy for further evaluations. Perhaps this metabolite has herbicidal properties or is associated with target site binding. Nonetheless, degradation rate of metamifop does not likely explain selectivity in tolerant and susceptible grasses.

ACCase Inhibition Assays. A species by metamifop concentration interaction was detected for ACCase inhibition; thus, results are presented across all combinations. The $\mathrm{I}_{50}$ for creeping bentgrass, Kentucky bluegrass, and goosegrass measured $>100,>100$, and $38 \mu \mathrm{M}$, respectively (Figure 8; Table 1). From contrast analysis, hierarchical rank of species for ACCase inhibition from high to low were:

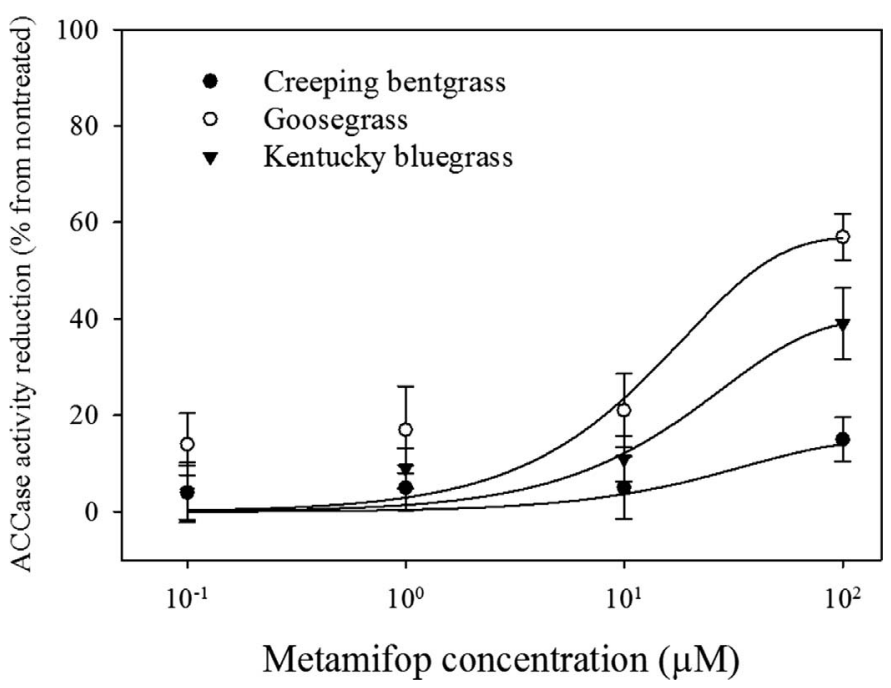

Figure 8. Isolated ACCase enzyme activity reduction from the nontreated for Penn A-4 creeping bentgrass, goosegrass, and Midnight Kentucky bluegrass at four metamifop concentrations in two experiments. Results were pooled over experimental runs. Vertical error bars represent standard error of means $(n=8)$. Data were regressed with the following equation: $y=\beta_{0}\{1-[\exp$ $\left.\left.\left(-\beta_{1} x\right)\right]\right\}$, where $y$ is absorption, $\beta_{0}$ is the asymptote, $\beta_{1}$ is the slope estimate, and $x$ is hours after treatment. Creeping bentgrass regression: $y=14.2\{1-[\exp (-0.03 x)]\}$. Goosegrass regression: $y=56.9\{1-[\exp (-0.05 x)]\}$. Kentucky bluegrass regression: $y=$ $35.5\{1-[\exp (-0.03 x)]\}$. Contrasts: creeping bentgrass vs. goosegrass $\mathrm{P}=0.0175$; goosegrass vs. Kentucky bluegrass $\mathrm{P}=$ 0.001 ; creeping bentgrass vs. goosegrass $\mathrm{P}=<0.0001$.

goosegrass $>$ Kentucky bluegrass $>$ creeping bentgrass (Figure 8). Kim et al. (2003) determined that the $\mathrm{I}_{50}$ of metamifop in barnyardgrass and rice measured 0.5 and $>10 \mu \mathrm{M}$, respectively. The researchers concluded that the selectivity of metamifop for barnyardgrass control in rice results from greater target site susceptibility. Similarly, the differential levels of ACCase inhibition contribute to the selectivity of metamifop for goosegrass control in tolerant turfgrasses.

Target site inhibition is a common mechanism attributed to the susceptibility or resistance of grasses to ACCase inhibitors (Burton et al 1989; Parker et al. 1990). Leach et al. (1995) reported that the $I_{50}$ of goosegrass ACCase for fluazifop and fenoxaprop ranged from 1.0 to $5.6 \mu \mathrm{M}$. Contrarily, the $\mathrm{I}_{50}$ for ACCase from a resistant biotype measured $>500$, $25 \mu \mathrm{M}$ for fluazifop and fenoxaprop, respectively. Kuk et al. (1999) proved ACCase activity from resistant smooth crabgrass was 50 -fold less sensitive to quizalofop-ethyl than a susceptible biotype. Similar differences in ACCase inhibition from AOPP herbicides were noted between resistant and susceptible biotypes of blackgrass, Japanese foxtail (Alopecurus japonicus Steud.), green foxtail, and rigid ryegrass (Lolium rigidum Gaud.) (DePrado et al. 2005; 
Marles et al. 1993; Moss et al. 2003; Yang et al. 2007).

A herbicide by concentration interaction was not detected for bermudagrass ACCase inhibition, and differences between herbicides were not detected (data not shown). Bermudagrass ACCase activity was linearly reduced with increased herbicide concentrations, and the $\mathrm{I}_{50}$ measured $0.7 \mu \mathrm{M}$. Results suggest bermudagrass ACCase is equally susceptible to inhibition by diclofop acid and metamifop. Therefore, bermudagrass tolerance to diclofopmethyl, compared with metamifop, is associated with degradation of diclofop acid to polar conjugates.

The influence of metabolism has been previously attributed to selectivity of AOPP herbicides in grasses with similar levels of target site inhibition. For example, Matthews et al. (1990) determined that ACCase inhibition by diclofop-methyl was similar in resistant and susceptible biotypes of Italian ryegrass (Lolium multiflorum Lam.). The researchers concluded that the resistance mechanisms were associated with herbicide detoxification. Similarly, Cocker et al. (2000) proved that fenoxaprop resistance in wild oat was not conferred by insensitive ACCase, but rather because of faster degradation than a susceptible biotype. Enhanced metabolism has also conferred resistance to diclofop-methyl in Italian ryegrass and rigid ryegrass compared with susceptible populations (DePrado et al. 2005; Preston and Powles 1998). Bermudagrass appears to detoxify diclofop-methyl and diclofop acid four to five times faster than metamifop. This level of degradation would likely minimize the availability of the herbicide to inhibit ACCase despite comparable levels of inhibition on isolated enzymes by the two herbicides.

Implications from This Research. Metamifop is a selective ACCase-inhibiting herbicide that will control bermudagrass and goosegrass in creeping bentgrass turf. Metamifop use could provide more sustainable management for creeping bentgrass culture by improving bermudagrass and goosegrass control efficacy with minimal turfgrass injury. Differences in ACCase inhibition are the physiological basis for metamifop selectivity for goosegrass control in creeping bentgrass and Kentucky bluegrass. The ACCase of bermudagrass appears equally susceptible to diclofop acid and metamifop, but detoxification of diclofop reduces injury potential compared with metamifop. Although metamifop is highly selective in creeping bentgrass and Kentucky bluegrass, ACCase resistance in annual grasses could limit the potential for effective weed control. Further research is needed to determine the efficacy of metamifop for controlling weeds with resistance to other ACCase inhibitors, such as sethoxydim, and the physiological basis for cross-resistance.

\section{Acknowledgments}

The authors thank Seth Williams and Brad Konwick for technical support with this research.

\section{Literature Cited}

Burton JD, Gronwald JW, Somers DA, Gengenbach BG, Wyse DL (1989) Inhibition of corn acetyl-CoA carboxylase by cyclohexanedione and aryloxyphenoxypropionate herbicides. Pestic Biochm Physiol 34:76-85

Carroll MJ, Mahoney MJ, Dernoeden PH (1992) Creeping bentgrass (Agrostis palustris) quality as influenced by multiple lowrate applications of fenoxaprop. Weed Technol 6:356-360

Chandresena NR, Sagar GR (1986) Uptake and translocation of ${ }^{14} \mathrm{C}$-fluazifop by quackgrass (Agropyron repens). Weed Sci 34:676-684

Cocker KM, Coleman JOD, Blair AM, Clarke JH, Moss SR (2000) Biochemical mechanisms of cross-resistance to aryloxyphenoxypropionate and cyclohexanedione herbicides in populations of Avena spp. Weed Res 40:323-334

Cronan JE, Waldrop GL (2002) Multi-subunit acetyl-CoA carboxylases. Prog Lipid Res 41:407-435

DePrado JL, Osuna MD, Heredia A, DePrado R (2005) Lolium rigidum, a pool of resistance mechanisms to ACCase inhibitor herbicides. J Agric Food Chem 53:2185-2191

Dernoeden P (1989) Mature creeping bentgrass and seedling Kentucky bluegrass tolerance to fenoxaprop. Int Turf Res J 6:279-283

Doroh MC, McElroy JS, van Santen E (2011) Evaluation of new aryloxypropionate herbicides for control of bermudagrass in zoysiagrass. Weed Technol 25:97-102

Flessner M, McElroy JS (2011) Potential use of metamifop for weed control in turfgrass [abstract]. In Annual meetings abstracts [CD-ROM]. Madison, WI: American Society of Agronomy, Crop Science Society of America, and Soil Science Society of America

Grafstron LD, Nalewaja JD (1988) Uptake and translocation of fluazifop in green foxtail (Setaria viridis). Weed Sci 36:153-158

Hae-Jin C., Kim H, Kim H, Kim S, Lee D, Hur J, Kim S (2002) Postemergence weed control with a mixture of pyrazosulfuron and metamifop in rice (Oryza sativa L. cv. Tongjin). J Agric Sci 13:89-96

Hart SE, Lycan DW, Murphy JA (2004) Response of creeping bentgrass (Agrostis stolonifera) to fall applications of bensulide and dithiopyr. Weed Technol 18:1072-1076

Hart SE, Mansue CJ (2010) Metamifop: a new postemergence herbicide for crabgrass and goosegrass control in cool-season turf. Pages 31-32 in Proceedings of the 19th Annual Rutgers Turfgrass Symposium. New Brunswick, NJ: Rutgers University Henry GM, Hart SE (2004) Velvet and creeping bentgrass tolerance to fenoxaprop. Hortscience 39:1768-1770 
Johnson BJ (1994a) Creeping bentgrass quality following preemergence and postemergence herbicide applications. Hortscience 29:880-883

Johnson BJ (1994b) Herbicide programs for large crabgrass and goosegrass control in Kentucky bluegrass turf. Hortscience 29:876-879

Johnson BJ, Carrow RN (1989) Bermudagrass encroachment into creeping bentgrass as affected by herbicides and plant growth regulators. Agron J 29:1220-1227

Johnson BJ, Carrow RN (1993) Bermudagrass (Cynodon spp.) suppression in creeping bentgrass (Agrostis stolonifera) with herbicide-flurprimidol treatments. Weed Sci 41:120-126

Johnson BJ, Carrow RN (1995) Influence of fenoxaprop and ethofumesate treatments on suppression of common bermudagrass (Cynodon dactylon) in tall fescue (Festuca arundinacea) turf. Weed Technol 9:789-793

Kim TJ, Chang HS, Kim JS, Hwang IT, Hong KS, Kim DW, Cho KY, Myung EJ, Chung BJ (2003) Metamifop: mechanism of herbicidal activity and selectivity in rice and barnyardgrass. Pages 833-838 in Proceedings of the BCPC International Congress: Crop Science and Technology. Volume 1. Glasgow, Scotland: British Crop Protection Council

Kuk YI, Wu J, Derr JF, Hatzios KK (1999) Mechanism of fenoxaprop resistance in an accession of smooth crabgrass (Digitaria ischaemum). Pestic Biochem Physiol 64:112-123

Leach GE, Devine MD, Kirkwood R, Marshall G (1995) Target enzyme-based resistance to acetyl-coenzyme A carboxylase inhibitors in Eleusine indica. Pestic Biochem Physiol 51:129-136

Marles MAS, Devine MD, Hal JC (1993) Herbicide resistance in Setaria viridis conferred by a less sensitive form of acetyl coenzyme A carboxylase. Pestic Biochem Physiol 46:7-14

Matthews JM, Holtum JAM, Liljegren D, Furness B, Powles S (1990) Cross-resistance to herbicides in annual ryegrass (Lolium rigidum): 1 . Properties of the herbicide target enzymes acetylcoenzyme A carboxylase and acetolactate synthase. Plant Physiol 94:1180-1186

McCarty LB (1991) Goosegrass (Eleusine indica) control in bermudagrass (Cynodon spp.) turf with diclofop. Weed Sci 39:255-261

McCarty LB, Miller LC, Colvin DL (1991) Bermduagrass (Cynodon spp.) cultivar response to diclofop, MSMA, and metribuzin. Weed Technol 5:27-32

McElroy JS, Rose JJ (2009) Creeping bentgrass and smooth crabgrass response to metamifop at two mowing heights. In Annual meetings abstracts [CD-ROM]. Madison, WI: American Society of Agronomy, Crop Science Society of America, and Soil Science Society of America
Mendez J, De Prado R (1996) Diclofop-methyl cross-resistance in a chlorotoluron-biotype of Alopecurus myosuroides. Pestic Biochem Physiol 56:123-133

Meyer JW, Branham BE (2006) Response of four turfgrass species to ethofumesate. Weed Technol 20:123-129

Moss S, Cocker KM, Brown AC, Hall L, Field LM (2003) Characterisation of target-site resistance to ACCase-inhibiting herbicides in the weed Alopecurus myosuroides (black-grass). Pest Manage Sci 59:190-201

Parker WB, Marshall LC, Burton JD, Somers DA, Wyse DL, Gronwald JW, Gengenbach BG (1990) Dominant mutations causing alterations in acetyl-coenzyme A carboxylase confer tolerance to cyclohexanedione and aryloxyphenoxypropionate herbicides in maize. Proc Natl Acad Sci USA 87:7175-7179

Preston C, Powles SB (1998) Amitrole inhibits diclofop metabolism and synergises diclofop-methyl in a diclofop-methyl-resistant biotype of Lolium rigidum. Pestic Biochem Physiol 62:179-189

Ruiz-Santaella JP, Heredia A, DePrado R (2006) Basis of selectivity of cyhalofop-butyl in Oryza sativa L. Planta 223:191-199

Seefeldt SS, Fuerst EP, Gealy DR, Shukla A, Irzyk GP, Devine MD (1996) Mechanisms of resistance to diclofop of two wild oat (Avena fatua) biotypes from the Willamette Valley of Oregon. Weed Sci 44:776-781

Shim SR, Johnson BJ (1992) Response of creeping bentgrass to spring-applied herbicides. Hortscience 27:237-239

Shimabukuro RH, Walsh WC, Hoerauf RA (1979) Metabolism and selectivity of diclofop-methyl in wild oat and wheat. J Agric Food Chem 27:615-622

Shukla A, Dupont S, Devine MD (1997) Resistance to ACCaseinhibitor herbicides in wild oat: evidence for target site-based resistance in two biotypes from Canada. Pestic Biochem Physiol 57:147-155

Siviour TR, Schultz GF (1984) Response of bermudagrass (Cynodon dactylon) to siduron. Weed Sci 32:178-180

Tardif FJ, Preston C, Holtum JAM, Powles SB (1996) Resistance to acetyl-coenzyme A carboxylase-inhibiting herbicides endowed by a single major gene encoding a resistant target site in a biotype of Lolium rigidum. Aust J Plant Physiol 23:15-23

Yang C, Dong L, Li J, Moss SR (2007) Identification of Japanese foxtail (Alopecurus japonicus) resistant to haloxyfop using three different assay techniques. Weed Sci 55:537-540

Received July 1, 2015, and approved August 19, 2015.

Associate Editor for this paper: Steven Seefeldt, University of Alaska at Fairbanks 